\title{
Study of the Formation of Amorphous Carbon and rGO-like Phases from Palmyra Sugar by Variation of Calcination Temperature
}

\author{
Fahmi Astuti*, Novita Sari, Vera Laviara Maghfirohtuzzoimah, Retno Asih, Malik Anjelh Baqiya, and Darminto \\ Department of Physics, Faculty of Science and Data Analytics, Institut Teknologi Sepuluh Nopember (ITS) \\ Kampus ITS Sukolilo, Surabaya 60111, Indonesia
}

\begin{abstract}
We have processed biomass from palmyra sugar to produce allotrope carbon by heating process with the variation of calcination temperature. The formation of amorphous carbon $(\mathrm{a}-\mathrm{C})$ was confirmed from the XRD result heated at $400^{\circ} \mathrm{C}$ with the observation of the peak at the position of $24^{\circ}$. By increasing the temperature at $700^{\circ} \mathrm{C}$, the presence of two peaks at $24^{\circ}$ and $43^{\circ}$ were observed, indicating the formation of rGO-like phase. The functional groups detected by FTIR spectra consist of $\mathrm{C}=\mathrm{C}, \mathrm{C}-\mathrm{O}, \mathrm{C}=\mathrm{O}, \mathrm{C}-\mathrm{H}$ and $\mathrm{O}-\mathrm{H}$. The conductivity measurement confirmed that the conductivity for a-C and $\mathrm{rGO}$ samples at room temperature are $4.50 \mathrm{~S} / \mathrm{m}$ and $6.53 \mathrm{~S} / \mathrm{m}$, respectively. The result of conductivity measurement exhibits that the material can be classified as semiconducting materials
\end{abstract}

Keywords: amorphous carbon; heating temperature; palmyra sugar; rGO.

*Corresponding author: fahmia@physics.its.ac.id, darminto@physics.its.ac.id

http://dx.doi.org/10.12962/j24604682.v16i2.6706

2460-4682 (C)Departemen Fisika, FSAD-ITS

\section{INTRODUCTION}

The study of carbon becomes attractive since the nobel prize award on graphene material in 2010 received by two scientists, Andre Geim and Konstantin Novoselov [1]. Carbon is one of the elements that is most widely studied and applied in various fields such as: supercapacitors, batteries, fuel cell electrodes and adsorbent materials [2,3]. Carbon has two main allotropes: crystalline (diamond, graphite and fullerene) and amorphous carbon [4]. Graphite consists of thin sheets of molecular bonding between carbon atom called graphene. As one of graphene derivatives, the graphene oxide (GO) consists of oxygen $(\mathrm{O})$ and hydrogen atoms $(\mathrm{H})$ which are bonded to carbon atoms in the hexagonal structure as shown in Fig. 1. The reduced graphene oxide is the reduction of graphene oxide that experiencing the loss of oxygen and hydrogen atoms [5]. Diamond and graphite, which are abundant allotropes of carbon, are diamagnetic materials owing to their orbital diamagnetism [6]. Amorphous carbon (aC) and reduced graphene oxide ( $\mathrm{rGO}$ ) contain mixtures of $\mathrm{sp}^{2}$ (graphitic) and $\mathrm{sp}^{3}$ (diamond) hybrids. They show semiconducting behavior and conduct electricity which can be used in some applications including its function for increasing the conductivity in secondary ion batteries, such as: Li- and Naion batteries $[7,8]$.

Coal based activated carbon products are commonly used across a large number of industries for a variety of applications. However, in order to make green alternatives to replace coal as a source of carbon, a carbon-based biomass is now being extensively studied. Carbon can be produced from heating of organic materials (waste recycling into advance products).
The production of allotropes carbon such as a-C and rGO using biomass has been studied in the past [9-14]. The formation of a-C and rGO are found by heating the coconut shell by variation of temperature $[11,12]$. In this study, we use another type of biomasses named palmyra sugar to produce a-C and rGO-like materials which has not been studied in the past. Indonesia becomes one of countries that has a large source of palmyra sugar $[15,16]$. The heating treatment with the variation of calcination temperature was used in this study to obtain allotropes carbon from biomass.

\section{METHODOLOGY}

The starting material was palmyra sugar from Lamongan, East Java, Indonesia. The palmyra sugar was heated at a temperature of $250^{\circ} \mathrm{C}$ at the ambient pressure for 2 hours to eliminate water contents. After obtaining the precursor, the sample was then calcinated at $400^{\circ} \mathrm{C}$ henceforth called as "sample 1 ". The other sample was obtained by calcinating the precursor at higher temperature of $700^{\circ} \mathrm{C}$ (called as "sample 2"). The products of calcinated samples were characterized by some experimental techniques. The thermogravimetric analysis and differential scanning calorimetry (TGA/DSC) were carried out to determine the decomposition temperatures. To analyze the composition of phases, the samples were characterized by the XRD (Philips XPert Multi Purpose Diffractometer) using $\mathrm{CuK} \alpha$ radiation $(\lambda=0.154056 \mathrm{~nm})$ at the angle of $5-60^{\circ}$. Functional groups presented in the samples were identified by the Fourier Transform Infrared measurement (8400S Shimadzu FTIR) in the range of $4000-500 \mathrm{~cm}^{-1}$. Conductivity measurement using four-point probe apparatus was also 


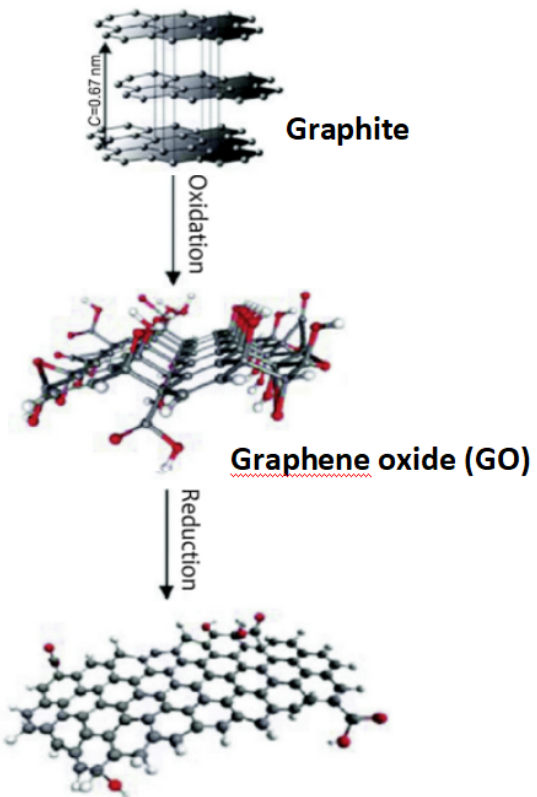

Reduced graphene oxide ( $r \mathrm{GO}$ )

FIG. 1: The chemical route to the reduced graphene oxide (rGO) [5].

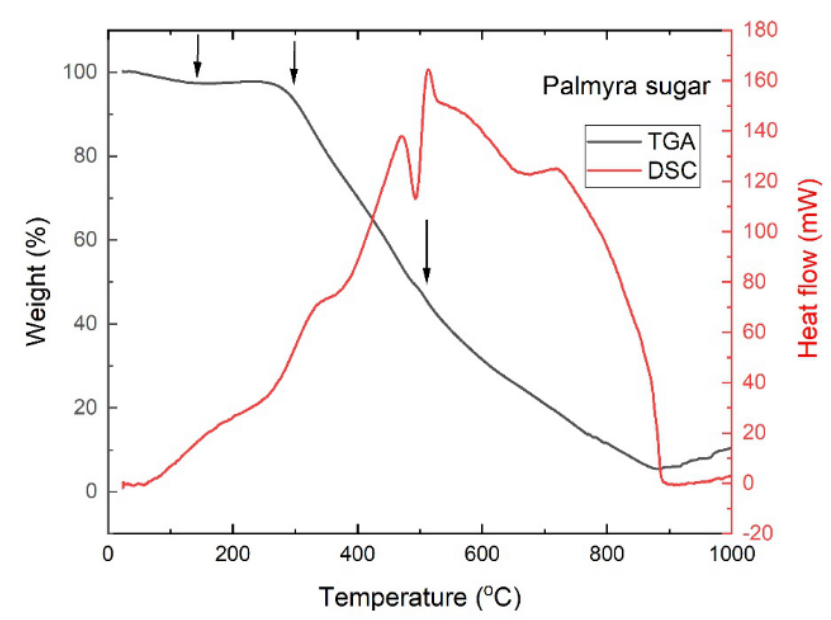

FIG. 2: Thermogravimetric and differential scanning calorimetry curve of heated palmyra sugar. Temperature is measured from room temperature to $1000^{\circ} \mathrm{C}$.

performed to check the electrical properties of samples.

\section{RESULTS AND DISCUSSION}

Fig. 2 displays TGA/DSC of the precursor from palmyra sugar, which is useful to determine the decomposition temperatures. The TGA/DSC curve of heated palmyra sugar shows thermal degradation at three stages. The weight loss in the first stage is about $3 \%$, within the temperature range

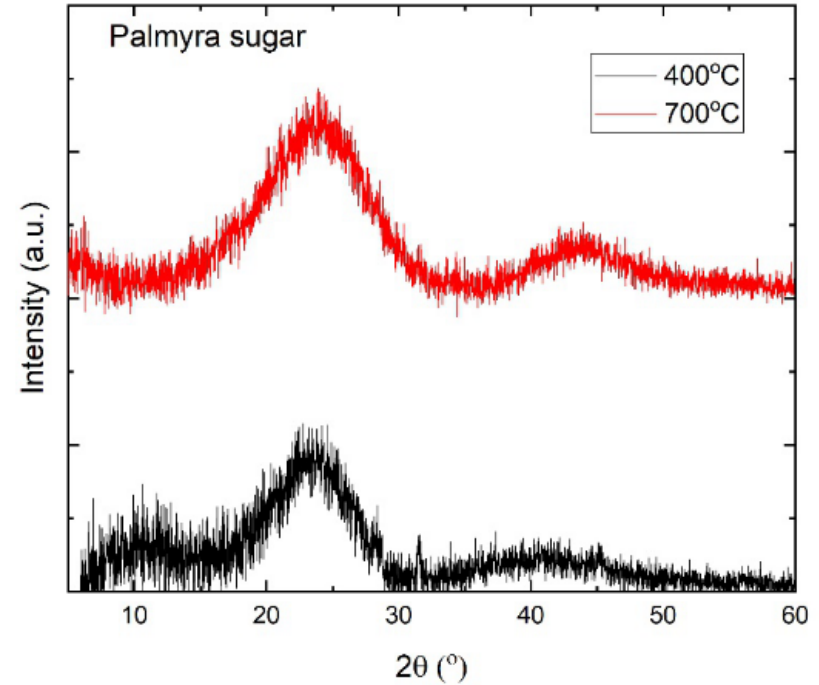

FIG. 3: XRD pattern of the powders from sample $1\left(400^{\circ} \mathrm{C}\right)$ and sample $2\left(700^{\circ} \mathrm{C}\right)$.

$150^{\circ} \mathrm{C}$ to $300^{\circ} \mathrm{C}$, coincidence with the endothermic reaction observed by DSC curve. The endothermic reaction at this stage can be attributed to the removal of adsorbed water. The second stage at $300^{\circ} \mathrm{C}$ to $500^{\circ} \mathrm{C}$ with $46 \%$ weight losses, followed by the third stage from $500^{\circ} \mathrm{C}$ to $876^{\circ} \mathrm{C}$ is observed. At this temperature range, the weight losses are attributed to the thermal degradation of hemicellulose and cellulose, forming a carbonaceous residue (rGO-like phase) from above $500^{\circ} \mathrm{C}$.

The formation of amorphous carbon (a-C) is confirmed from the XRD result of sample 1 with the observation of the peak at the position of $\sim 24^{\circ}$ as shown in Fig. 3. A broadening XRD pattern is an indication of amorphous state of this sample. By increasing the temperature at $700^{\circ} \mathrm{C}$, the presence of two peaks at $24^{\circ}$ and $43^{\circ}$ were observed in sample 2, indicating the formation of rGO-like phase. The XRD pattern of a-C and rGO-like phase obtained in this result are similar to that of reported in Ref. [17-20]. As mentioned in Ref. [20], the broad peak of $\sim 24^{\circ}$ is (002) plane which can be attributed to the amorphous carbon structure. The weak and broad diffraction peak of $43^{\circ}$ can be attributed to (101) or (102) plane of rGO structure [20,21].

As shown in Fig. 4, the functional groups detected by the FTIR spectra are consisted of $\mathrm{C}=\mathrm{C}, \mathrm{C}-\mathrm{O}, \mathrm{C}=\mathrm{O}, \mathrm{C}-\mathrm{H}$ and $\mathrm{O}$ $\mathrm{H}$. The $\mathrm{C}-\mathrm{H}$ stretch is observed at $870 \mathrm{~cm}^{-1}, 1440 \mathrm{~cm}^{-1}$ and $2917 \mathrm{~cm}^{-1}$. A broad $\mathrm{OH}$ vibration peak is observed at $3436 \mathrm{~cm}^{-1}$ which is similar to that of in Ref. [19], displaying that absorption bands in the range between 3373-3546 $\mathrm{cm}^{-1}$ are associated to the symmetrical stretching of hydroxyl groups $(\mathrm{OH})$. Other transmittance peaks in the FTIR spectrum are observed at $1157 \mathrm{~cm}^{-1}$ (CO stretching vibrations), at $1689 \mathrm{~cm}^{-1}$ (CO stretching vibrations) and at $1582 \mathrm{~cm}^{-1}$ (CC stretching vibrations). The $\mathrm{C}=\mathrm{C}$ are attributed to $\mathrm{sp}^{2}$ config- 


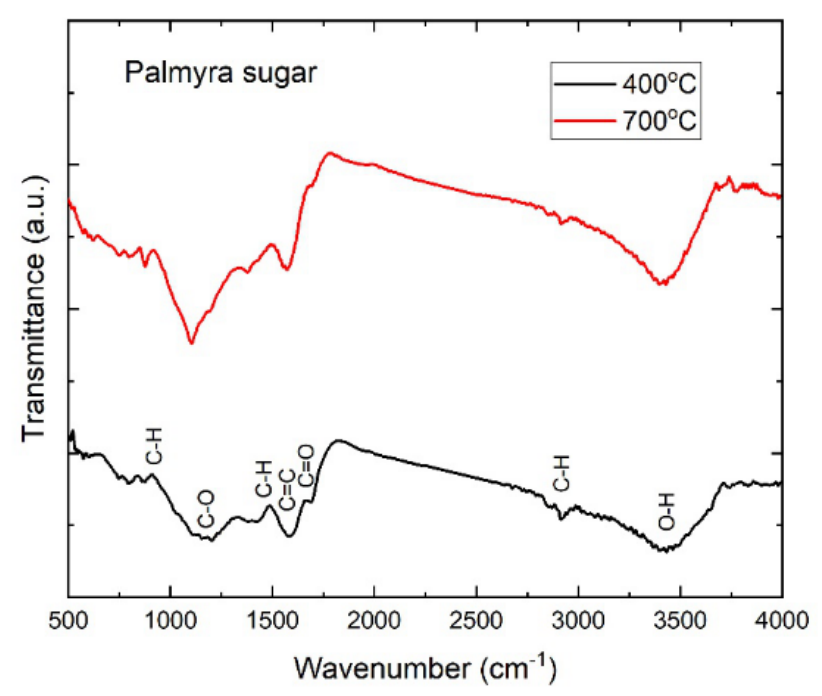

FIG. 4: FTIR results of the powders from sample $1\left(400^{\circ} \mathrm{C}\right)$ and sample $2\left(700^{\circ} \mathrm{C}\right)$.

TABLE I: Comparison of conductivity in various allotrope carbon in different temperature.

\begin{tabular}{lccc}
\hline \hline Sample & $\begin{array}{c}\text { Conductivity } \\
(\mathrm{S} / \mathrm{m})\end{array}$ & $\begin{array}{c}\text { Temperature } \\
(\mathrm{K})\end{array}$ & Ref. \\
\hline Sample 1 & 4.50 & 300 & Present work \\
Sample 2 & 6.53 & 300 & Present work \\
rGO film & $6.3 \times 10^{5}$ & 300 & {$[23]$} \\
rGO film & $5.4 \times 10^{5}$ & 2 & {$[23]$} \\
GO film & $59 \times 10^{2}$ & 773 & {$[24]$} \\
rGO nanosheets & $5.32 \times 10^{2}$ & 230 & {$[25]$} \\
a-C: H & 0.3 & 348 & {$[26]$} \\
a-C thin films & $1.88 \times 10^{-2}$ & 300 & {$[27]$} \\
\hline
\end{tabular}

uration. By increasing the temperature at $700^{\circ} \mathrm{C}$, the appearance of $\mathrm{C}=\mathrm{C}$ bonding is more obvious than that of at $400^{\circ} \mathrm{C}$ as exhibited in Fig. 4. The presence of clear $\mathrm{C}=\mathrm{C}$ bonding as one of functional groups is also detected in rGO in Ref. [22].

The conductivity measurement confirms that the magnitude of conductivity for sample 1 and sample 2 at room temperature are $4.50 \mathrm{~S} / \mathrm{m}$ and $6.53 \mathrm{~S} / \mathrm{m}$, respectively. The value of conductivity is in the range of semiconducting materials. The semiconducting material has a range of electrical conductivity in the range of $1 \times 10^{-8} \mathrm{~S} / \mathrm{m}$ to $0.1 \times$ $10^{6} \mathrm{~S} / \mathrm{m}$ as also indicated in other references as displayed in Table I [11]. It has been reviewed as well in this table that the temperature strongly affects the conductivity. Based on our recent data, the TGA/DSC measurement could provide information of the condition to form a-C and $\mathrm{rGO}$ from palmyra sugar. XRD and FTIR results are also able to show the formation of a-C and $\mathrm{rGO}$ from the heated palmyra sugar. The result of conductivity measurement exhibits that the material can be classified as semiconducting materials which is a characteristic of a-C and rGO. Therefore, this report can show the alternative to produce allotrope carbon from biomasses, specifically using palmyra sugar.

\section{SUMMARY}

We have processed biomass from palmyra sugar to produce allotrope carbon by heating process with the variation of calcination temperature. The formation of amorphous carbon (a-C) was confirmed from the XRD result heated at $400^{\circ} \mathrm{C}$ with the observation of the peak at the position of $24^{\circ}$. By increasing the temperature at $700^{\circ} \mathrm{C}$, the presence of two peaks at $24^{\circ}$ and $43^{\circ}$ were observed, indicating the formation of rGOlike phase. The functional groups detected by FTIR spectra consist of $\mathrm{C}=\mathrm{C}, \mathrm{C}-\mathrm{O}, \mathrm{C}=\mathrm{O}, \mathrm{C}-\mathrm{H}$ and $\mathrm{O}-\mathrm{H}$. The conductivity measurement confirmed that the conductivity of a-C and $\mathrm{rGO}$ samples at room temperature are $4.50 \mathrm{~S} / \mathrm{m}$ and $6.53 \mathrm{~S} / \mathrm{m}$, respectively. The result of conductivity measurement exhibits that the material can be classified as semiconducting materials. This report is able to show the alternative to produce allotrope carbon from biomass.

\section{Acknowledgments}

This research was partially supported by Hibah PDUPT 2019. The authors would like to thank Research Center, Institut Teknologi Sepuluh Nopember Surabaya for the experimental apparatus.
[1] A.K. Geim, K. S. Novoselov, "The rise of graphene", Nat. Mat., vol. 6, pp. 183-191, 2007.

[2] S. Miyoshi, et al., "Fast diffusivity of PF6-Anions in graphitic carbon for a dual-carbon rechargeable battery with superior rate property", J. Phys. Chem. C, vol. 40, pp. 22887-22894, 2016.

[3] C.-F. Liu, Y.-C. Liu, T.-Y. Yu, and C.-C. Hu, "Carbon materials for high-voltage supercapacitors", Carbon, vol. 145, pp. 529$548,2019$.

[4] S.H. Dhawane, T. Kumar, and G. Halder, "Recent advancement and prospective of heterogeneous carbonaceous catalysts in chemical and enzymatic transformation of biodiesel", Energy
Conserve. Manage., vol. 167, pp. 176-202, 2018.

[5] Q. Ke, and J. Wang, "Graphene-based materials for supercapacitor electrodesA review", J. Materiomics, vol. 2, pp. 37-54, 2016.

[6] P. Esquinazi, and R. Hhne, "Magnetism in carbon structures", J. Magn. Magn. Mater, vol. 290, pp. 20-27, 2005.

[7] S. Kugler, et al., "Amorphous Semiconductors", Cambridge University Press, Cambridge, 2015.

[8] K. Morigaki, et al., "Amorphous Semiconductors Structural, Optical, and Electronic Properties", Wiley Series in Materials for Electronic and Optoelectronic Applications, United States, 
2017.

[9] S. Gurunathan, J.W. Han, V. Eppakayala, and J.-H. Kim, "Green synthesis of graphene and its cytotoxic effects in human breast cancer cells", International Journal of Nanomedicine, vol. 8, pp. 1015-1027, 2013.

[10] S. S. Shams, L.S.Zhang, R. Hu, R. Zhang, and J. Zhu, "Synthesis of graphene from biomass: A green chemistry approach", Mat. Lett., vol. 161, pp. 476-479, 2015.

[11] A. Y. Nugraheni, M. Nashrullah, F.A. Prasetya, F. Astuti, and Darminto, "Study on phase, molecular bonding, and bandgap of reduced graphene oxide prepared by heating coconut shell", Materials Science Forum, vol. 827, pp. 285-289, 2015.

[12] K.W. Masudah, I.M.A. Nugraha, S. Abidin, A. Mufid, F. Astuti, and Darminto, "Solution of reduced graphene oxide synthesized from coconut shells and its optical properties", AIP Conf. Proc., vol. 1586, pp. 202-206, 2014.

[13] W. Islamiyah, L. Nashirudin, M.A. Baqiya, Y. Cahyono, and Darminto, "Sulfuric acid intercalated-mechanical exfoliation of reduced graphene oxide from old coconut shell", AIP Conf. Proc., vol. 1945 (020054), pp. 1-5, 2018.

[14] Kurniasari, A. Maulana, A.Y. Nugraheni, D.N. Jayanti, S. Mustofa, M.A. Baqiya, and Darminto, "Defect and magnetic properties of reduced graphene oxide prepared from old coconut shell", Proc. IOP Conf. Mater, Sci. Eng., vol. 196, 012021, 2017.

[15] A. Tomomatsu, T. Itoh, C.H. Wijaya, Z. Nasution, J. Kumendong, and A. Matsuyama, "Chemical constituents of sugarcontaining sap and brown sugar from palm in Indonesia", Jpn. J. Trop. Agr., vol. 40, pp. 175-181, 1996.

[16] T. A. Davis and D.V. Johnson, "Current utilization and further development of the palmyra palm (Borassus flabellifer L.,Arecaceae) in Tamil Nadu State, India”, Economic Botany, vol. 41, pp. 247-266, 1987.

[17] S. Suganuma, K. Nakajima, M. Kitano, D. Yamaguchi, H. Kato, S. Hayashi, and M. Hara, "Hydrolisis of cellulose by amorphous carbon bearing $\mathrm{SO} 3 \mathrm{H}, \mathrm{COOH}$, and $\mathrm{OH}$ groups", J. Am. Chem. Soc., vol. 130, pp. 12787-12793, 2008.

[18] L.-Romero, and C. Ramrez, "Synthesis of TiC thin films by
CVD from toluene and titanium tetrachloride with nickel as catalyst", Revista Matria, vol. 12, pp. 487-493, 2007.

[19] S. Lanfredi, M.A.L. Nobre, P.S. Poon, and J. Matos, "Hybrid material based on an amorphous-carbon matrix and $\mathrm{ZnO} / \mathrm{Zn}$ for the solar photocatalytic degradation of basic blue 41", Molecules, vol. 25, no. 1, pp. 96, 2020.

[20] B. Gupta, N. Kumar, K. Panda, V. Kanan, S. Joshi, and I.V.Fisher, "Role of oxygen functional groups in reduced graphene oxide for lubrication", Sci. Rep., vol. 7, pp. 45030, 2017.

[21] X.-Y. Liu, et al., "Preparation of a carbon-based solid acid catalyst by sulfonating activated carbon in a chemical reduction process", Molecules, vol. 15, pp. 7188-7196, 2010.

[22] R.A. Rochman, S. Wahyuningsih, A.H. Ramelan, and Q.A. Hanif, "Preparation of nitrogen and sulphur Co-doped reduced graphene oxide (rGO-NS) using $\mathrm{N}$ and $\mathrm{S}$ heteroatom of thiourea", IOP. Conf. Series: Materials Science and Engineering, vol. 509, 012119, 2019.

[23] Y. Wang, Y. Chen, S.D. Lacey, L. Xu, H. Xie, T. Li, V.A. Danner, and $\mathrm{L}$. Hu, "Reduced graphene oxide film with record-high conductivity and mobility", Materials Today, vol. 21, pp. 186192, 2018.

[24] H. Chen, M.B. Mller, K.J. Gilmore, G.G. Wallace, and D. Li, "Mechanically strong, electrically conductive, and biocompatible graphene paper", Adv. Mater., vol. 20, pp. 3557-3561, 2009.

[25] K. Liu, S. Ronca, E.A.-Reyes, G. Forte, and S. Rastogi, "Unique rheological response of ultrahigh molecular weight polyethylenes in the presence of reduced graphene oxide", Macromolecules, vol. 48, pp. 131-139, 2015.

[26] D. Dasgupta, F. Demichelis, and A. Tagliaferro, "Electrical conductivity of amorphous carbon and amorphous hydrogenated carbon”, Philosophical Magazine Part B, vol. 63, no. 6, pp. 1255-1266, 2006.

[27] A.N. Fadzilah, K. Dayana, U.M. Noor, and M. Rusop, "Optoelectrical properties of amorphous carbon thin films deposited by aerosol-assisted chemical vapor deposition", IEEE Symposium On Humanities, Science and Engineering Research, pp. 887-892, 2012. 